Alicia Alonso Álvarez

Lucía Ramos Merino

Laura María Castelo Corral

Ana Padín Trigo

Dolores Sousa Regueiro

Enrique Míguez Rey

Efrén Sánchez Vidal

\title{
Ceftaroline fosamil: clinical experience after 23-month prescription in a tertiary hospital
}

Infectious Disease Department, Complejo Hospitalario Universitario A Coruña

Article history

Received: 9 October 2020; Revision Requested: 12 January 2021; Revision Received: 7 February 2021; Accepted: 8 February 2021; Published: 15 February 2021

\section{ABSTRACT}

Objective. To determine the indications, success rate and adverse effects of ceftaroline fosamil treatment in a tertiary hospital.

Material and methods. In total, 84 cases from February 2018 to December 2019 were retrospectively analysed. No exclusion criteria were applied.

Results. Eighty-four patients, with a median age of 70 years, of which, 6.7\% (56) were male, were treated with ceftaroline fosamil for a median of 14 days. Most indications were off-label, including 29 endocarditis (34.5\%), 14 bacteraemia (16.6\%), 5 Central nervous system (CNS) infections (6\%) and 19 osteoarticular infections (22.6\%). Staphylococcus. aureus was the most frequently isolated microorganism, including 28 methicillin-sensitive S. aureus (MSSA; 33.3\%) and 14 methicillin-resistant S. aureus (MRSA; 16.7\%), followed by coagulase-negative Staphylococcus $(23,27.4 \%)$. The main reason for ceftaroline fosamil prescription was the failure of previous treatment (41.7\% of cases). Treatment was successful in 60/84 patients (71.4\%) and failed clinically or microbiologically in 14 (16.7\%). Eight patients died for a reason not related to the infection and two were found to have a non-infectious condition. Twenty-two of thirty-five (62.8\%) patients prescribed ceftaroline because of failure of previous treatment improved, including eight endocarditis and seven bacteraemia. Adverse effects were reported in five patients (5.9\%) including neutropenia, thrombocytopenia, transaminases elevation and creatinine elevation; all except one were mild and all resolved after discontinuation of treatment.

Conclusions. Ceftaroline fosamil is a well-tolerated ceph-

Correspondence:

Efrén Sánchez Vidal

Infectious Diseases Department, Complejo Hospitalario Universitario A Coruña

Calle As Xubias, 84. 15006. A Coruña (A Coruña). Spain

Phone: +34 981178157

E-mail: efren.sanchez.vidal@sergas.es alosporine, effective against multi- resistant gram-positive and many gram-negative microorganisms. Our experience suggests that it is effective as a rescue or first-line therapy in other indications than those currently approved.

Keywords: ceftaroline fosamil, off-label, endocarditis

Ceftarolina fosamil: experiencia clínica tras 23 meses de uso en un hospital de tercer nivel

\section{RESUMEN}

Introducción. Determinar las indicaciones, tasa de éxito y efectos adversos del tratamiento con ceftarolina fosamil en un hospital terciario.

Material y métodos. Se analizaron retrospectivamente 84 casos desde febrero de 2018 a diciembre de 2019. No se aplicaron criterios de exclusión.

Resultados. Ochenta y cuatro pacientes, con una mediana de edad de 70 años, de los cuales el 6,7\% (56) eran varones, fueron tratados con ceftarolina fosamil durante una mediana de 14 días. La mayoría de las indicaciones se realizaron fuera de ficha técnica, incluidas 29 endocarditis (34,5\%), 14 bacteriemias (16,6\%), 5 infecciones de sistema nervioso central (6\%) y 19 infecciones osteoarticulares (22,6\%). Staphylococcus aureus fue el microorganismo aislado con más frecuencia, incluidos 28 S. aureus sensibles a meticilina (SASM; 33,3\%) y 14 S. aureus resistentes a meticilina (SARM; 16,7\%), seguidos por Staphylococcus coagulasa negativo $(23,27,4 \%)$. El principal motivo de prescripción de ceftarolina fosamil fue el fracaso del tratamiento previo (41,7\% de los casos). El tratamiento fue un éxito en $60 / 84$ pacientes $(71,4 \%)$ y fracasó clínica o microbiológicamente en 14 (16,7\%). Ocho pacientes murieron por una causa no relacionada con la infección y dos tenían un proceso no infeccioso. Veintidós de treinta y cinco $(62,8 \%)$ pacientes a los que se les prescribió ceftarolina debido al fracaso del tratamiento previo mejoraron, incluidas ocho endocarditis y siete 
bacteriemias. Cinco pacientes (5,9\%) presentaron efectos adversos que incluyen neutropenia, trombocitopenia, elevación de transaminasas y elevación de creatinina; todos excepto uno fueron leves y todos se resolvieron después de la interrupción del tratamiento.

Conclusiones. Ceftarolina fosamil es una cefalosporina bien tolerada, eficaz contra microorganismos grampositivos multirresistentes y muchos gramnegativos. Nuestra experiencia sugiere que es eficaz como terapia de rescate o de primera línea en otras indicaciones distintas de las aprobadas actualmente.

Palabras clave: ceftarolina fosamil, fuera de indicación, endocarditis

\section{INTRODUCTION}

Ceftaroline fosamil was approved by de European Medicines Agency in 2012 for use in community-acquired pneumonia as well as acute skin and soft tissue infections. It is a fifth-generation cephalosporine and the first beta-lactam active against multi-resistant gram-positive microorganisms, including methicillin-resistant Staphylococcus aureus (MRSA), methicillin-resistant coagulase-negative staphylococci and penicillin-resistant Streptococcus pneumoniae. This is based on its mechanism of action with high affinity for MRSA PBP2a, S. pneumoniae PBP2x and E. faecalis PBP5. It is also effective for many non-producing extended-spectrum beta-lactamase or AmpC-derepressed Enterobacteriaceae. Furthermore, it encompasses all of the advantages of the de beta-lactam family, including effective bactericide and good tolerability [1]. The efficacy and safety for the treatment of pneumonia and soft tissue infection were evaluated in the FOCUS and CANVAS studies, respectively $[2,3]$. Since then, some observational studies and case series have addressed its usefulness beyond label indications but data from randomised control trials is lacking [4]. We present a real-life setting study of the prescription of ceftaroline fosamil over 23 months in a tertiary hospital.

\section{MATERIAL AND METHODS}

All patients prescribed ceftaroline in our tertiary care hospital from February 2018 to December 2019 were retrospectively revised. Data were obtained from electronic medical records. No exclusion criteria were applied. SPSS statistics V 20.0 software was used, and 36 variables were analysed.

\section{RESULTS}

In total, 84 patients received ceftaroline fosamil for a median of 14 days (interquartile range, 9 to 31 days) from February 2018 to December 2019. The median age was 70 years and $66.7 \%$ (56) were male. The median Charlson comorbidity index was 4 points, $30 \%$ of patients were diabetic, $44.8 \%$ had any heart disease, $22.7 \%$ had a chronic renal injury, $14.3 \%$ had neoplasms, 17.9\% had a chronic pulmonary disease, 9.5\% had chronic liver disfunction and $4.8 \%$ were transplant recipients. Most patients (88.1\%) received ceftaroline under the supervision of the Infectious Disease Department, 54 in a medical ward, 16 in a surgical section, and 14 in an ICU setting.

Most indications were off-label, including 29 (34.5\%) infectious endocarditis (IE), of which 20 were prosthetic valve IE and 9 native valve IE; 14 (16.6\%) bacteraemia, 19 (22.6\%) osteoarticular infections and $5(6 \%)$ central nervous system (CNS) infections; 2 (2.4\%) patients had a complicated skin and soft tissue infection and 10 (11.9\%) patients had pneumonia. Of the remaining five patients, one had tertiary peritonitis with the isolation of methicillin-resistant

S. epidermidis, one S. pneumoniae bacteraemia secondary to complicated sinusitis with an intraorbital abscess, one had a sternal wound infection and was reported previous myositis due to daptomycin, and the fourth was a patient under oral treatment for chronic osteomyelitis who developed biliary sepsis; the reason for prescribing ceftaroline was unspecified for the fifth patient.

\section{\begin{tabular}{l|l} 
Table 1 & Description of secondary effects
\end{tabular}}

\begin{tabular}{|c|c|c|c|c|}
\hline Case & Secondary effect & Figure & Day of appearance & Evolution after discontinuation \\
\hline \multirow[t]{3}{*}{1} & Transaminases elevation & GGT 140 IU/L (NR 8-61) & 38 & Normalization 6 days after \\
\hline & & ALT 107 IU/L (NR 5-45) & & \\
\hline & & AST 48 IU/L (NR 5-40) LDH 625 IU/L (NR 219- 439) & & \\
\hline 2 & Neutropenia & 490 neutrophils/L & 38 & Normalization 12 days after \\
\hline 3 & Neutropenia, thrombocytopenia & 440 neutrophils/L $76 \times 10^{9}$ platelets/L & 32 & Normalization 5 months after ${ }^{\mathrm{a}}$ \\
\hline 4 & Thrombocytopenia, creatinine elevation & $88 \times 10^{9}$ platelets $/ \mathrm{L}$ creatinine $2.01 \mathrm{mg} / \mathrm{dL}$ & 13 & $\begin{array}{l}\text { Normalization of platelet count } 10 \text { days after, } \\
\text { creatinine improved to } 1.3 \mathrm{mg} / \mathrm{dL}^{\mathrm{b}}\end{array}$ \\
\hline 5 & Neutropenia & 130 neutrophils/L & 18 & Normalization 6 days after \\
\hline
\end{tabular}

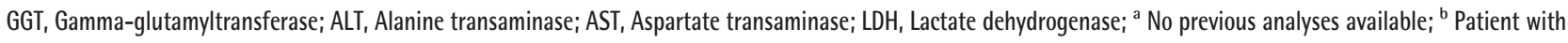
acute multi-factorial kidney injury; role of Ceftaroline is speculative 


\begin{tabular}{l|cccc}
\hline Table 2 & \multicolumn{4}{l}{$\begin{array}{l}\text { Patients in which ceftaroline was prescribed } \\
\text { because of failure of previous treatment: } \\
\text { evolution and infection type }\end{array}$} \\
\hline & Success & Failure & Dead no related to infection & Total \\
\hline Osteomyelitis & 0 & 1 & 0 & 1 \\
\hline Arthritis & 0 & 1 & 0 & 1 \\
\hline Bacteraemia & 7 & 1 & 0 & 8 \\
\hline Endocarditis & 8 & 5 & 0 & 13 \\
\hline Pneumonia & 5 & 1 & 0 & 6 \\
\hline CNS infection & 1 & 1 & 1 & 3 \\
\hline Other & $1^{\text {a }}$ & $1^{b}$ & 1 & 3 \\
\hline Total & 22 & 11 & 2 & 35 \\
\hline
\end{tabular}

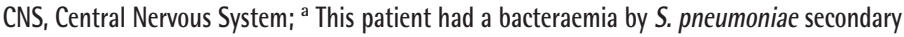
to a complicated sinusitis and intraorbital abscess; ${ }^{\text {This }}$ was a multi-operated patient with tertiary peritonitis; Ceftaroline was added to treatment because of previous methicillin resistant S. epidermidis isolation. Nevertheless, his general condition worsened and required new surgical intervention.

\section{Table 3}

Patients in which ceftaroline was prescribed because of failure of previous treatment: evolution and microorganism

\begin{tabular}{lcccc}
\hline & Success & Failure & Dead no related to infection & Total \\
\hline Coagulase-negative staphylococci & 6 & 4 & 0 & 10 \\
\hline Methicillin-susceptible S. aureus & 11 & 1 & 0 & 12 \\
Methicillin-resistant S. aureus & 2 & 2 & 0 & 4 \\
Enterococcus sp. & 0 & 1 & 0 & 1 \\
Streptococcus sp. & 2 & 0 & 1 & 3 \\
No isolation & 1 & 3 & 1 & 5 \\
Total & 22 & 11 & 2 & 35 \\
\hline
\end{tabular}

Causative microorganisms were isolated in 72 patients, with $S$. aureus being the most common pathogen (28 methicillin-susceptible S. aureus (MSSA) and 14 MRSA), followed by coagulase-negative staphylococci (23), streptococci (3) and enterococci (2).

The main reason for prescription was the failure of previous treatment (35 patients, 41.7\%), defined as a lack of clinical improvement or isolation of the same microorganism 48 hours after initiation of an appropriate antibiotic. Ceftaroline was the drug of-choice in 40 (47.6\%) patients, in an empirical (27) or guided (13) manner. In seven patients, the reason for prescription was unspecified and in two patients, previous adverse drug effects prompted the change to the antimicrobial regimen.

Most patients $(52,61.9 \%)$ received $600 \mathrm{mg}$ every 8 hours, $14(16.6 \%)$ were given $600 \mathrm{mg}$ every 12 hours, with the remaining treatments adjusted by renal function.
Secondary effects were reported in five patients (5.9\%) including neutropenia, thrombocytopenia, transaminases elevation and creatinine elevation; all except one were mild and resolved after discontinuation (Table 1).

Success was defined as satisfactory clinical evolution which allowed treatment discontinuation or de-escalation and was obtained in most patients $(60,71.4 \%)$. Two patients $(2.4 \%)$ in which treatment was empirical were found to have a non-infectious condition. 8 (9.5\%) of them died for a reason not related to the infection. Treatment failure, defined as adverse clinical evolution or persistence of positive cultures for the same microorganism 48 hours after ceftaroline initiation, occurred in 14 (16.7\%) patients. Of note, 78.5\% (11) of these failures occurred in patients for which ceftaroline had been prescribed because of the failure of previous antibiotics. Nevertheless, most cases in which ceftaroline was the salvage treatment recovered $(22 / 35,62.8 \%)$ (Table 2 and 3 ). 


\section{DISCUSSION}

Clinical data on the effectivity of ceftaroline in off-label indications in scarce and rests upon case series, fundamentally used as salvage therapy [5-11]. One recent large multicentre retrospective study included 527 patients and most (67\%) were treated for off-label infections [12], a lower rate than in our series in which this group of patients represented $85.7 \%$ of the cases. Notably, these included 5 CNS infections (6\%) and 19 osteoarticular infections (22.6\%), in which previous experience is even more scarce $[9-11,13]$.

Of note, MSSA was isolated in 28/72 (38.8\%) of patients in our series, a high incidence compared to previous reports [14]. For most patients, the reason for prescription was the failure of previous treatment (12 patients, 42.9\%) or an empirical of-choice treatment in patients with risk factors for MRSA (12 patients, 42.9\%). Most patients $(18,64.3 \%)$ had endocarditis or bacteraemia, life-threatening, infections with a high inoculum in which treatment with a broad- spectrum and high bactericidal antibiotic is mandatory. Importantly, 26 of these MSSA isolates showed a MIC to vancomycin $1.5 \mathrm{~g} / \mathrm{mL}$ as measured by the E-test.

Interestingly, 47.6\% of patients received ceftaroline as the first-choice therapy without previous antibiotic treatment, a higher percentage than the previous series [12]. Arshad et al concluded in their retrospective control-matched comparative study [15] that ceftaroline is clinically as effective as vancomycin or daptomycin for treatment of MRSA bacteraemia. In our study, 15 of 40 patients treated with ceftaroline as first-line therapy had bacteraemia or endocarditis, 15 had an osteoarticular infection, of which eight were prosthetic arthritis. In this group of patients, the high bactericidal power of ceftaroline against resistant gram-positive bacteria combines with its activity against many non-resistant Enterobacteriaceae, microorganisms which may affect such patients, especially older patients, thus allowing an empirical antibiotic regimen with one single agent.

Our study correlates with previous literature regarding the rate of clinical or microbiological cure, which was $71.4 \%$, comparable to $68.3 \%$ reported by Zasowski et al [16].

Regarding the dosage of ceftaroline, it has been previously proposed that $600 \mathrm{mg}$ every 8 hours instead of every 12 hours would be more effective in patients with normal renal function, especially if the risk of MRSA infection is high [17]. The tolerance of this regimen was compared to standard therapy by Cheng et al [18], who found a comparable safety profile. In our study, most patients (60\%) received $600 \mathrm{mg}$ every 8 hours, with good tolerance in most patients. The rate of adverse effects was similar to those described previously in the literature [14] (5/84 patients, 5.9\%). All events occurred in patients who received $600 \mathrm{mg}$ every 8 hours after 2 weeks of treatment. Remarkably, 3 of 5 patients suffered neutropenia. La Vie et al [19] reported a high rate of neutropenia associated with prolonged ceftaroline use in a series of 39 patients, and recommended a weekly blood count, whereas data from large multicentre controlled trials reported a lower incidence of haematological toxicity [20]. Disturbances in liver tests and renal function impairment have been described in $1-7 \%$ and $<1 \%$ of patients in previous studies, respectively [20].

This retrospective study confirms the previous evidence of ceftaroline fosamil good tolerability and effectiveness against multi-resistant gram-positive microorganisms, providing new data to support its use in currently off-label indications as rescue or first-line therapy.

\section{FUNDING}

None to declare.

\section{CONFLICT OF INTEREST}

Efrén Sánchez, Enrique Míguez and Dolores Sousa have received some speaker honoraria from Pfizer. The other authors have no conflicts of interest

\section{REFERENCES}

1. Horcajada JP, Cantón R. Ceftarolina, un nuevo antimicrobiano de amplio espectro en la era de las multirresistencias. Enferm Infecc Microbiol Clin. 2014;32(SUPPL. 2):1-7. doi:10.1016/S0213005X(14)70151-X

2. File, Jr TM, Low DE, Eckburg PB, Talbot GH, Firedland HD, Lee J, et al. Integrated Analysis of FOCUS 1 and FOCUS 2: Randomized, Doubled-Blinded, Multicenter Phase 3 Trials of the Efficacy and Safety of Ceftaroline Fosamil versus Ceftriaxone in Patients with Community-Acquired Pneumonia. Clin Infect Dis. 2010;51(12):1395-1405. doi:10.1086/657313

3. Corey GR, Wilcox M, Talbot GH, Friedland HD, Baculik T, Witherell GW, et al. Integrated Analysis of CANVAS 1 and 2: Phase 3, Multicenter, Randomized, Double-Blind Studies to Evaluate the Safety and Efficacy of Ceftaroline versus Vancomycin plus Aztreonam in Complicated Skin and Skin-Structure Infection. Clin Infect Dis. 2010;51(6):641-650. doi:10.1086/655827

4. Pani A, Colombo F, Agnelli F, Frantellizzi V, Baratta F, Pastori D, Scaglione F. Off-label use of ceftaroline fosamil: A systematic review. Int J Antimicrob Agents. 2019. doi:10.1016/j.ijantimicag.2019.06.025

5. Ho T, Cadena J, Childs LM, Gonzalez-Velez M, Lewis JS. Methicillin-resistant Staphylococcus aureus bacteraemia and endocarditis treated with ceftaroline salvage therapy. J Antimicrob Chemother. 2012;67(5):1267-1270. doi:10.1093/jac/dks006

6. Polenakovik HM, Pleiman CM. Ceftaroline for meticillin-resistant Staphylococcus aureus bacteraemia: Case series and review of the literature. Int J Antimicrob Agents. 2013;42(5):450- 455. doi:10.1016/j.ijantimicag.2013.07.005

7. Almirante B, Pericás JM, Miró JM. Papel de la ceftarolina fosamil en el tratamiento de la bacteriemia y la endocarditis infecciosa. Enferm Infecc Microbiol Clin. 2014;32(SUPPL. 2):44-53. doi:10.1016/ S0213-005X(14)70158-2 
8. Lin JC, Aung $G$, Thomas $A$, Jahng $M$, Johns $S$, Fierer J. The use of ceftaroline fosamil in methicillin-resistant Staphylococcus aureus endocarditis and deep-seated MRSA infections: A retrospective case series of 10 patients. J Infect Chemother. 2013;19(1):42-49. doi:10.1007/s10156-012-0449-9

9. Reinoso JC, Cardenal JA. Utilidad potencial de ceftarolina fosamil en las infecciones osteoarticulares. Enferm Infecc Microbiol Clin. 2014;32(SUPPL. 2):32-37. doi:10.1016/S0213-005X(14)70156-9

10. Balouch MA, Bajwa RJ, Hassoun A. Successful use of ceftaroline for the treatment of mrsa meningitis secondary to an infectious complication of lumbar spine surgery. J Antimicrob Chemother. 2015;70(2):624-625. doi:10.1093/jac/dku392

11. Bucheit J, Collins R, Joshi P. Methicillin-resistant Staphylococcus aureus epidural abscess treated with ceftaroline fosamil salvage therapy. Am J Heal Pharm. 2014;71(2):110-113. doi:10.2146/ ajhp130246

12. Casapao AM, Davis SL, Barr VO, Klinker KP, Goff DA, Barber KE, et al. Large retrospective evaluation of the effectiveness and safety of ceftaroline fosamil therapy. Antimicrob Agents Chemother. 2014;58(5):2541-2546. doi:10.1128/AAC.02371-13

13. Cottagnoud $P$, Cottagnoud $M$, Acosta $F$, Stucki A. Efficacy of ceftaroline fosamil against penicillin-sensitive and -resistant streptococcus pneumoniae in an experimental rabbit meningitis model. Antimicrob Agents Chemother. 2013;57(10):4653-4655. doi:10.1128/AAC.00286-13

14. Sakoulas G, Moise PA, Casapao AM, Nonejuie P, Olson J, Okumura CYM, et al. Antimicrobial salvage therapy for persistent staphylococcal bacteremia using daptomycin plus ceftaroline. Clin Ther. 2014;36(10):1317-1333. doi:10.1016/j.clinthera.2014.05.061

15. Arshad S, Huang V, Hartman P, Perri MB, Moreno D, Zervos MJ. Ceftaroline fosamil monotherapy for methicillin-resistant Staphylococcus aureus bacteremia: a comparative clinical outcomes study. Int J Infect Dis. 2017;57:27-31. doi:10.1016/j.ijid.2017.01.019

16. Zasowski EJ, Trinh TD, Claeys KC, Casapao AM, Sabagha N, Lagnf AM, et al. Multicenter observational study of ceftaroline fosamil for methicillin-resistant Staphylococcus aureus bloodstream infections. Antimicrob Agents Chemother. 2017;61(2). doi:10.1128/AAC.02015- 16

17. Canut A, Isla A, Rodríguez-Gascón A. Pharmacokinetic/pharmacodynamic analysis to evaluate ceftaroline fosamil dosing regimens for the treatment of community-acquired bacterial pneumonia and complicated skin and skin-structure infections in patients with normal and impaired renal function. Int J Antimicrob Agents. 2015;45(4):399-405. doi:10.1016/j.jantimicag.2014.12.023

18. Cheng K, Pypstra R, Yan JL, Hammond J. Summary of the safety and tolerability of two treatment regimens of ceftaroline fosamil: $600 \mathrm{mg}$ every $8 \mathrm{~h}$ versus 600mg every $12 \mathrm{~h}$. J Antimicrob Chemother. 2019;74(4):1086-1091. doi:10.1093/jac/dky519

19. LaVie KW, Anderson SW, O'Neal HR, Rice TW, Saavedra TC, O'Neal CS. Neutropenia associated with long-term ceftaroline use. Antimicrob Agents Chemother. 2016;60(1):264- 269. doi:10.1128/ AAC.01471-15

20. File TM, Wilcox MH, Stein GE. Summary of ceftaroline fosamil clinical trial studies and clinical safety. Clin Infect Dis. 2012;55(SUPPL. 3):173-180. doi:10.1093/cid/cis559 